\title{
Biochemical Assessment of Possible Protective Role of Kombucha Tea against Stressful Effect Induced by High Sucrose Dose
}

\author{
H. A. Abdel Maksoud ${ }^{1}$, Raafat R. Mohammed ${ }^{1}$, Mohamed G. Elharrif ${ }^{2}$ and \\ Nedal S. Abdulatif ${ }^{1}$ \\ 1Department of Biochemistry, Benha University, Egypt \\ ${ }^{2}$ Department of Basic Medical Sciences, Shaqra University, KSA
}

\begin{abstract}
Kombucha tea is highly fermented beverage popularly consumed in many countries. The aim was to evaluate the possible protective effects of the usage of Kombucha as natural agent against the stressful effects resulted from administration of high sucrose diet to male rabbits through determination of some biochemical parameters. The results demonstrated that pretreatment with Kombucha tea in high sucrose stressed rabbit significantly improve lipid profile and antioxidant system meanwhile significant reduction of glucose, urea, creatinine, cupper and non significant change in testosterone and copper levels. In conclusion, Kombucha tea was able to ameliorate serum biochemical parameters in high sucrose stressed rabbits mediated by antioxidant and lipotropic properties.
\end{abstract}

Keywords: Antioxidant, Anti-Atherosclerotic Effect, Hypoglycemic Effect, Rabbit

\section{Introduction}

The history of Kombucha referred to a Korean physician called Kombu, who was the first to introduce this beverage to Japanese importer (as a drink with healing properties). It is prepared by fermenting black tea with a special culture of yeasts and bacteria known as Kombucha mushroom. It is not really a mushroom, but that's how people call it because of its shape and color when it starts forming on top of the tea after the fermentation process, but there are lots of different preparation methods and different culture that can be used. Once the beverage is finally prepared, it contains a certain amount of alcohol, acetic acid and ethyl acetate ${ }^{1}$.

Kombucha has shown many beneficial health effects like improved energy levels, weight loss, detoxifier, antioxidants as well as antimicrobial activity against different types of bacteria like Escherichia coli, Staphylococcus aureus, Helicobacter pylori and Agrobacterium tumefaciens ${ }^{3}$.
Kombucha tea is rich with nutritive properties, beneficial bacteria, multivitamins, enzymes and essential organic acids such as acetic acid, lactic acid, folic acid, gluconic acid, glucuronic acid, usnic acid, ascorbic acid and oxalic acid which helps liver in removing toxic substances ${ }^{6}$.

Sucrose is a non-reducing disaccharide made up of $50 \%$ glucose and $50 \%$ fructose and has a moderately high glycemic index of $80^{10}$. Sucrose is broken down into its constituent monosaccharides, glucose and fructose by sucrase and/or isomaltase enzymes, which are located in the membrane of the microvilli lining the duodenum ${ }^{14}$.

High sucrose diet are contributed to a number of abnormalities, which include cardiovascular and renal disease such as hypertension, hypertriglyceridemia, increased collagen deposition in the heart and kidneys associated with increased oxidant concentrations and decreased antioxidant defenses as well as glucose intolerance in addition to hyper-insulinemia ${ }^{13}$. 
The present study was planned to show the possible effects of the usage of Kombucha as natural protective agent against the adverse stressful effects resulted from administration of high sucrose diet to male rabbits on some biochemical constituents.

\section{Materials and Methods}

\subsection{Preparation of Kombucha Tea}

Preparation of Kombucha tea was done according to ${ }^{1,3}$.

- Five gram of green tea leaves was soaked in one liter of freshly-boiled water for 15 minutes. The tea leaves were strained through a sieve (as green tea contains less caffeine than black tea).

- About 70-100 g of white sugar per liter of water was dissolved into the filtered infusion before it cooled.

- Then the tea was cooled to $20-25{ }^{\circ} \mathrm{C}$. The solution was poured into a glass container. The shape of the container is unimportant but larger diameter containers work better because that allows more oxygen to get to the tea.

- Kombucha culture was added and the fermentation container was covered with a tightly, multiple layers of cheese cloth or a paper towel and was secured with a rubber band (the cloth should be porous enough to allow air to circulate so the culture can breathe, but not so porous that contamination can occur).

- The fermentation process was allowed to take place for 7-12 days (depending on the faster the fermentation the shorter period will need to be). The Kombucha culture should not be moved during this period. The temperature of the tea should fall between $20^{\circ} \mathrm{C}$ and $30^{\circ} \mathrm{C}$.

- When the tea has attained the right degree of acidity (pH 2.7-3.2), it is ready for use.

\subsection{Laboratory Animals}

Eighty male rabbits at age of 4 weeks old after winning and weighting about 500-600 gm were used in the experimental investigations of this study. Rabbits were obtained from "The Laboratory Animals Research Center", Benha University and housed in separate wire mesh cages, exposed to good ventilation, humidity and to a 12-hr light/dark cycle.

Animals were left for 15 days for acclimatization prior to the beginning of the experiment to ensure normal growth and behavior and kept at constant environmental and nutritional conditions on a basal ration of standard pellet diet, fresh and clean drinking water were supplied ad-libitum.

\section{Experimental Design}

Acclimatized rabbits were randomly allocated into 4 groups as following:

Rabbits were allocated into 4 groups as following:

- First Group (Control): Twenty rabbits, served as control, kept on basal ration only.

- Second Group (Sucrose Stressed): Twenty rabbits reared on the $25 \%$ sucrose concentration ration only.

- Third Group (Kombucha): Twenty rabbits were fed on normal diet and Kombucha solution $(150 \mathrm{ml})$.

- Fourth Group (Kombucha protected): Twenty rabbits kept on equal amounts of $25 \%$ sucrose and Kombucha solution $(150 \mathrm{ml})$.

\subsection{Collection of Blood Samples}

Blood samples were collected from all animals under experiment monthly for 4 month by ear veins in first and third sample then by slaughtering of half of rabbits in each group (Ten rabbits) in second and last sample.

Blood samples were collected in tubes without anticoagulant in clean, dry Wassermann tubes and left in slope position to clot at room temperature. The tubes were centrifuged at $3000 \mathrm{rpm}$ for 5 minutes and the non hemolyzed serum was carefully separated and transferred into clean dry Eppendorf tubes which were kept frozen at $-20^{\circ} \mathrm{C}$ until used for biochemical analysis.

All serum samples were analyzed for the determination of lipid profile (Total lipids, TAG, Total Cholesterol, HDL-C LDL-C, VLDL-C and Atherogenic Indices). As well as urea, creatinine, glucose, testosterone, zinc and copper were also determined. 


\subsection{Collection of Rabbit's Liver, Heart and Kidney}

After collection of the $2^{\text {nd }}$ and $4^{\text {th }}$ blood samples, 10 rabbits were sacrificed after two months from beginning of the experiment and the rest of 10 rabbits were sacrificed after 4 months. The liver, heart and kidney were removed and washed by ice-cold saline buffer to remove the blood and then blotted in filter papers and finally kept frozen at $-20^{\circ} \mathrm{C}$ for biochemical analysis.

All tissues samples were analyzed for the determination of reduced Glutathione (GSH) and antioxidant enzymes (Catalase and GST), L-malondialdehyde (L-MDA) and $\mathrm{H}_{2} \mathrm{O}_{2}$.

\section{Results and Discussion}

Kombucha is a highly fermented tea beverage popularly consumed as a self prescribed folk remedy for numerous ailments. Kombucha is claimed to enhance cognition, aid weight loss, and prolonged life ${ }^{9}$.

Fructose is a major ingredient of many processed foods and has been proposed to contribute to the development of obesity and dyslipidemia. Diets rich in fructose induce hepatic steatosis and plasma hyperlipidemia ${ }^{2}$. Our data was in agreement with earlier studies ${ }^{5}$, a short term consumption of a high-sucrose diet increases the triglyceride levels in liver and plasma. The increment in total lipids may attribute to fructose which has been shown to increase plasma concentrations of triacylglycerols and cholesterol.

Table 1. The effect of Kombucha supplementation on serum lipid profile in normal and sucrose stressed male rabbits

\begin{tabular}{cccccc}
\hline \multirow{2}{*}{ parameter } & Groups & \multicolumn{4}{c}{ Sample interval } \\
\cline { 3 - 5 } & & $\mathbf{1}^{\text {st }}$ month & $\mathbf{2}^{\text {nd }}$ month & $\mathbf{3}^{\text {rd }}$ month & $\mathbf{4}^{\text {th }}$ month \\
\hline \multirow{3}{*}{ Total lipids $(\mathrm{mg} / \mathrm{dl})$} & Control & $241.05 \pm 5.75$ & $248.44 \pm 4.83$ & $287.36 \pm 4.01$ & $314.58 \pm 4.37$ \\
& Sucrose Stressed & $378.30 \pm 8.85$ & $396.18 \pm 7.29$ & $414.46 \pm 6.56$ & $451.75 \pm 7.14$ \\
& Kombucha only & $269.61 \pm 6.41$ & $282.50 \pm 5.51$ & $323.30 \pm 8.96$ & $360.23 \pm 9.76$ \\
& Kombucha + Sucrose & $322.53 \pm 8.26$ & $339.27 \pm 8.53$ & $36.61 \pm 4.81$ & $397.72 \pm 5.24$ \\
& Control & $36.68 \pm 1.86$ & $52.00 \pm 1.94$ & $93.50 \pm 1.12$ & $101.91 \pm 1.20$ \\
Triacylglycerols $(\mathrm{mg} / \mathrm{dl})$ & Sucrose Stressed & $161.25 \pm 5.44$ & $236.05 \pm 8.51$ & $223.18 \pm 2.57$ & $274.78 \pm 2.79$ \\
& Kombucha only & $56.08 \pm 5.06$ & $104.24 \pm 4.84$ & $80.67 \pm 1.94$ & $131.13 \pm 2.11$ \\
& Kombucha + Sucrose & $105.39 \pm 3.89$ & $166.57 \pm 4.25$ & $126.79 \pm 4.00$ & $161.30 \pm 4.36$ \\
& Control & $49.50 \pm 3.49$ & $58.32 \pm 4.17$ & $70.63 \pm 2.97$ & $76.98 \pm 3.22$ \\
Totalcholesterol $(\mathrm{mg} / \mathrm{dl})$ & Sucrose Stressed & $63.86 \pm 5.09$ & $70.11 \pm 3.49$ & $75.64 \pm 1.83$ & $82.44 \pm 1.99$ \\
& Kombucha only & $38.75 \pm 1.39$ & $53.46 \pm 2.92$ & $62.52 \pm 2.09$ & $68.14 \pm 2.27$ \\
& Kombucha + Sucrose & $57.71 \pm 2.23$ & $58.87 \pm 3.05$ & $68.09 \pm 1.79$ & $75.39 \pm 1.94$ \\
& Control & $28.77 \pm 0.98$ & $26.26 \pm 24.10$ & $20.41 \pm 1.78$ & $22.24 \pm 193$ \\
& Sucrose Stressed & $12.24 \pm 1.99$ & $10.87 \pm 0.97$ & $9.33 \pm 1.04$ & $8.54 \pm 1.13$ \\
HDL-C $(\mathrm{mg} / \mathrm{dl})$ & Kombucha only & $15.16 \pm 1.92$ & $22.74 \pm 1.60$ & $16.91 \pm 1.31$ & $17.06 \pm 1.32$ \\
& Kombucha + Sucrose & $22.74 \pm 1.60$ & $24.42 \pm 1.18$ & $20.56 \pm 1.46$ & $20.75 \pm 1.48$ \\
& Control & $14.19 \pm 3.22$ & $14.90 \pm 2.53$ & $15.31 \pm 1.95$ & $15.88 \pm 2.12$ \\
& Sucrose Stressed & $15.55 \pm 0.86$ & $23.13 \pm 2.34$ & $16.63 \pm 1.95$ & $19.10 \pm 1.79$ \\
& Kombucha only & $11.16 \pm 1.97$ & $12.39 \pm 1.36$ & $13.80 \pm 1.31$ & $15.04 \pm 1.42$ \\
VLDL-C $(\mathrm{mg} / \mathrm{dl})$ & Kombucha + Sucrose & $13.30 \pm 16.32$ & $19.67 \pm 1.06$ & $13.50 \pm 0.97$ & $14.70 \pm 1.05$ \\
& Control & $7.33 \pm 0.37$ & $10.40 \pm 0.38$ & $18.69 \pm 1.08$ & $20.36 \pm 1.17$ \\
& Kucrose Stressed & $32.24 \pm 3.88$ & $47.20 \pm 3.00$ & $42.47 \pm 0.50$ & $46.28 \pm 0.55$ \\
& Kombucha only & $21.22 \pm 3.88$ & $23.40 \pm 0.84$ & $27.97 \pm 0.37$ & $26.33 \pm 0.40$ \\
& Kombucha + Sucrose & $22.52 \pm 0.77$ & $30.07 \pm 0.85$ & $35.07 \pm 0.79$ & $36.57 \pm 0.86$ \\
\hline & & & &
\end{tabular}


Biochemical Assessment of Possible Protective Role of Kombucha Tea against Stressful Effect Induced by High Sucrose Dose

Table 2. The effect of Kombucha supplementation on atherogenic indices in normal and sucrose stressed male rabbits

\begin{tabular}{|c|c|c|c|c|c|}
\hline \multirow{2}{*}{ parameter } & \multirow{2}{*}{ Groups } & \multicolumn{4}{|c|}{ Sample interval } \\
\hline & & $1^{\text {st }}$ month & $2^{\text {nd }}$ month & $3^{\text {rd }}$ month & $4^{\text {th }}$ month \\
\hline \multirow{4}{*}{ Cardiac risk ratio (CRR) } & Control & $1.53 \pm 0.14$ & $2.40 \pm 0.31$ & $3.46 \pm 0.45$ & $3.76 \pm 0.48$ \\
\hline & Sucrose Stressed & $5.06 \pm 0.87$ & $4.71 \pm 0.32$ & $8.26 \pm 95.25$ & $8.99 \pm 103.82$ \\
\hline & Kombuchaonly & $1.74 \pm 1.08$ & $2.46 \pm 0.29$ & $4.07 \pm 0.38$ & $4.42 \pm 0.42$ \\
\hline & Kombucha + Sucrose & $2.54 \pm 0.25$ & $1.93 \pm 0.11$ & $3.40 \pm 0.29$ & $3.70 \pm 0.31$ \\
\hline \multirow{4}{*}{ Atherogenic index (AI) ratio } & Control & $0.10 \pm 0.03$ & $0.32 \pm 0.10$ & $0.64 \pm 0.02$ & $0.70 \pm 0.02$ \\
\hline & Sucrose Stressed & $1.03 \pm 0.09$ & $1.17 \pm 0.02$ & $1.32 \pm 0.03$ & $1.44 \pm 0.03$ \\
\hline & Kombuchaonly & $0.86 \pm 0.02$ & $0.70 \pm 0.02$ & $0.68 \pm 0.03$ & $0.73 \pm 0.03$ \\
\hline & Kombucha + Sucrose & $0.79 \pm 0.03$ & $0.72 \pm 0.02$ & $0.58 \pm 0.04$ & $0.62 \pm 0.04$ \\
\hline \multirow{4}{*}{ Atherogenic Coefficient (AC) } & Control & $0.82 \pm 0.14$ & $1.43 \pm 0.31$ & $2.49 \pm 0.46$ & $2.71 \pm 0.49$ \\
\hline & Sucrose Stressed & $4.09 \pm 0.87$ & $3.74 \pm 0.32$ & $7.29 \pm 0.95$ & $7.93 \pm 1.02$ \\
\hline & Kombuchaonly & $0.77 \pm 0.09$ & $1.92 \pm 0.29$ & $3.20 \pm 0.38$ & $3.58 \pm 0.42$ \\
\hline & Kombucha + Sucrose & $1.76 \pm 0.25$ & $0.96 \pm 0.11$ & $2.43 \pm 0.29$ & $2.64 \pm 0.31$ \\
\hline
\end{tabular}

Table 3. The effect of Kombucha supplementation on serum urea, creatinine and glucose in normal and sucrose stressed male rabbits

\begin{tabular}{cccccc}
\hline \multirow{2}{*}{ parameter } & \multirow{2}{*}{ Groups } & \multicolumn{4}{c}{ Sample interval } \\
\cline { 3 - 6 } & & $\mathbf{1}^{\text {st }}$ month & $\mathbf{2}^{\text {nd }}$ month & $\mathbf{3}^{\text {rd }}$ month & $\mathbf{4}^{\text {th }}$ month \\
\hline \multirow{4}{*}{ Urea $(\mathrm{mg} / \mathrm{dl})$} & Control & $24.30 \pm 1.72$ & $29.16 \pm 1.04$ & $31.10 \pm 0.75$ & $31.65 \pm 1.13$ \\
& Sucrose Stressed & $24.30 \pm 0.62$ & $33.04 \pm 1.42$ & $32.07 \pm 1.42$ & $34.95 \pm 1.52$ \\
& Kombucha only & $19.87 \pm 1.00$ & $25.27 \pm 1.38$ & $26.24 \pm 1.81$ & $28.59 \pm 1.97$ \\
& Kombucha + Sucrose & $18.70 \pm 1.59$ & $2.10 \pm 1.73$ & $25.27 \pm 1.53$ & $27.54 \pm 1.26$ \\
& Control & $0.63 \pm 0.03$ & $0.58 \pm 0.03$ & $0.74 \pm 0.07$ & $0.81 \pm 0.07$ \\
Creatinine level $(\mathrm{mg} / \mathrm{dl})$ & Sucrose Stressed & $0.68 \pm 0.03$ & $0.65 \pm 0.05$ & $0.77 \pm 0.03$ & $0.84 \pm 0.03$ \\
& Kombucha only & $0.60 \pm 0.02$ & $0.55 \pm 0.05$ & $0.70 \pm 0.01$ & $0.75 \pm 0.01$ \\
& Kombucha + Sucrose & $0.41 \pm 0.02$ & $0.48 \pm 0.03$ & $0.68 \pm 0.03$ & $0.73 \pm 0.03$ \\
& Control & $84.31 \pm 2.32$ & $91.41 \pm 2.94$ & $101.08 \pm 6.02$ & $110.18 \pm 3.28$ \\
Glucose level (mg/dl) & Sucrose Stressed & $98.56 \pm 2.27$ & $129.76 \pm 2.01$ & $174.96 \pm 3.27$ & $95.35 \pm 3.56$ \\
& Kombucha only & $79.21 \pm 1.62$ & $85.05 \pm 17.75$ & $87.48 \pm 3.27$ & $95.35 \pm 3.56$ \\
& Kombucha + Sucrose & $81.11 \pm 2.87$ & $105.81 \pm 2.35$ & $119.14 \pm 3.07$ & $137.74 \pm 3.34$ \\
\hline
\end{tabular}

Table 4. The effect of Kombucha supplementation on serum testosterone, zinc and copper in normal and sucrose stressed male rabbits

\begin{tabular}{|c|c|c|c|c|c|}
\hline \multirow{2}{*}{ Parameter } & \multirow{2}{*}{ Groups } & \multicolumn{4}{|c|}{ Sample interval } \\
\hline & & $1^{\text {st }}$ month & $2^{\text {nd }}$ month & $3^{\text {rd }}$ month & $4^{\text {th }}$ month \\
\hline \multirow{4}{*}{$\begin{array}{l}\text { Testosterone } \\
\text { concentration } \\
(\mathrm{ng} / \mathrm{ml})\end{array}$} & Control & $1.32 \pm 0.04$ & $1.80 \pm 0.18$ & $2.01 \pm 0.23$ & $1.93 \pm 0.34$ \\
\hline & Sucrose Stressed & $1.56 \pm 0.14$ & $2.13 \pm 0.27$ & $3.11 \pm 0.38$ & $3.18 \pm 0.35$ \\
\hline & Kombucha only & $0.98 \pm 0.03$ & $1.03 \pm 0.06$ & $1.05 \pm 0.03$ & $1.37 \pm 0.27$ \\
\hline & Kombucha + Sucrose & $1.16 \pm 0.02$ & $1.19 \pm 0.05$ & $1.09 \pm 0.05$ & $1.06 \pm 0.32$ \\
\hline \multirow{4}{*}{$\begin{array}{l}\text { Zinc concentration } \\
\qquad(\mu \mathrm{g} / \mathrm{dl})\end{array}$} & Control & $177.62 \pm 2.38$ & $185.40 \pm 4.37$ & $205.74 \pm 6.15$ & $227.78 \pm 6.70$ \\
\hline & Sucrose Stressed & $141.50 \pm 3.57$ & $156.89 \pm 6.12$ & $165.61 \pm 4.05$ & $175.12 \pm 4.40$ \\
\hline & Kombucha only & $194.15 \pm 1.99$ & $200.23 \pm 2.72$ & $218.34 \pm 5.34$ & $228.57 \pm 5.82$ \\
\hline & Kombucha + Sucrose & $159.69 \pm 3.00$ & $171.03 \pm 2.78$ & $179.49 \pm 6.75$ & $196.39 \pm 7.35$ \\
\hline
\end{tabular}




\begin{tabular}{cccccc} 
& Control & $23.81 \pm 1.59$ & $25.60 \pm 1.04$ & $28.91 \pm 2.71$ & $30.48 \pm 2.16$ \\
Copper concentration & Sucrose Stressed & $3.47 \pm 1.60$ & $46.87 \pm 1.32$ & $53.97 \pm 1.63$ & $62.76 \pm 2.13$ \\
$(\mu \mathrm{g} / \mathrm{dl})$ & Kombucha only & $26.87 \pm 1.06$ & $27.70 \pm 0.73$ & $29.80 \pm 1.20$ & $32.54 \pm 3.24$ \\
& Kombucha + Sucrose & $38.97 \pm 1.04$ & $33.82 \pm 0.58$ & $30.94 \pm 2.18$ & $25.64 \pm 2.36$ \\
\hline
\end{tabular}

Table 5. The effect of Kombucha supplementation on liver, heart and kidney - reduced glutathione (GSH), antioxidant enzymes (Catalase and GST), L-malondialdehyde (L-MDA) and $\mathrm{H}_{2} \mathrm{O}_{2}$ in normal and sucrose stressed male rabbits

\begin{tabular}{|c|c|c|c|c|c|c|c|}
\hline \multirow[b]{2}{*}{ parameter } & \multirow[b]{2}{*}{ Groups } & \multicolumn{2}{|c|}{ Liver } & \multicolumn{2}{|c|}{ Heart } & \multicolumn{2}{|c|}{ Kidney } \\
\hline & & $\begin{array}{l}\text { After } 2 \\
\text { months }\end{array}$ & $\begin{array}{l}\text { After } 4 \\
\text { months }\end{array}$ & $\begin{array}{l}\text { After } 2 \\
\text { months }\end{array}$ & $\begin{array}{c}\text { After } 4 \\
\text { months }\end{array}$ & $\begin{array}{l}\text { After } 2 \\
\text { months }\end{array}$ & $\begin{array}{c}\text { After } 4 \\
\text { months }\end{array}$ \\
\hline \multirow{4}{*}{$\begin{array}{c}\text { GSH } \\
\text { (mg/g. } \\
\text { tissue) }\end{array}$} & Control & $723.89 \pm 29.63$ & $666.13 \pm 27.06$ & $35.22 \pm 1.26$ & $31.28 \pm 1.19$ & $96.71 \pm 2.14$ & $88.86 \pm 1.99$ \\
\hline & $\begin{array}{l}\text { Sucrose } \\
\text { Stressed }\end{array}$ & $397.89 \pm 20.50$ & $336.26 \pm 21.83$ & $21.35 \pm 0.82$ & $17.16 \pm 0.75$ & $35.37 \pm 2.70$ & $29.41 \pm 6.73$ \\
\hline & $\begin{array}{c}\text { Kombucha } \\
\text { only }\end{array}$ & $771.62 \pm 20.41$ & $797.23 \pm 23.43$ & $39.79 \pm 1.27$ & $33.56 \pm 1.15$ & $102.85 \pm 4.35$ & $94.61 \pm 2.45$ \\
\hline & $\begin{array}{l}\text { Kombucha } \\
\text { + Sucrose }\end{array}$ & $528.28 \pm 28.29$ & $567.69 \pm 23.98$ & $26.67 \pm 1.42$ & $22.07 \pm 1.26$ & $75.06 \pm 4.38$ & $62.15 \pm 4.15$ \\
\hline \multirow{4}{*}{$\begin{array}{c}\text { Catalase } \\
\text { (U/g. tissue) }\end{array}$} & Control & $316.76 \pm 14.16$ & $300.92 \pm 13.87$ & $78.55 \pm 3.09$ & $74.97 \pm 2.93$ & $272.88 \pm 3.79$ & $\begin{array}{c}254.91 \pm \\
10.27\end{array}$ \\
\hline & $\begin{array}{l}\text { Sucrose } \\
\text { Stressed }\end{array}$ & $218.60 \pm 12.52$ & $187.80 \pm 12.32$ & $37.44 \pm 1.51$ & $31.14 \pm 12.27$ & $125.51 \pm 8.37$ & $109.16 \pm 7.77$ \\
\hline & $\begin{array}{c}\text { Kombucha } \\
\text { only }\end{array}$ & $342.19 \pm 13.82$ & $323.81 \pm 13.54$ & $84.47 \pm 0.82$ & $79.41 \pm 0.74$ & $213.03 \pm 4.47$ & $197.41 \pm 9.46$ \\
\hline & $\begin{array}{l}\text { Kombucha } \\
+ \text { Sucrose }\end{array}$ & $274.61 \pm 11.71$ & $261.40 \pm 14.73$ & $64.62 \pm 4.66$ & $55.76 \pm 4.14$ & $258.55 \pm 5.68$ & $230.10 \pm 9.37$ \\
\hline \multirow{4}{*}{$\begin{array}{c}\text { GST } \\
\text { activity } \\
\text { (U/g. tissue) }\end{array}$} & Control & $301.77 \pm 4.38$ & $287.75 \pm 4.15$ & $146.39 \pm 3.56$ & $139.07 \pm 4.02$ & $273.85 \pm 9.97$ & $260.16 \pm 9.47$ \\
\hline & $\begin{array}{l}\text { Sucrose } \\
\text { Stressed }\end{array}$ & $209.34 \pm 2.40$ & $186.31 \pm 2.23$ & $85.44 \pm 4.14$ & $69.63 \pm 3.85$ & $114.37 \pm 12.26$ & $93.29 \pm 11.40$ \\
\hline & $\begin{array}{c}\text { Kombucha } \\
\text { only }\end{array}$ & $320.02 \pm 9.93$ & $300.94 \pm 9.03$ & $149.52 \pm 3.69$ & $144.99 \pm 3.35$ & $260.19 \pm 2.07$ & $247.83 \pm 1.79$ \\
\hline & $\begin{array}{l}\text { Kombucha } \\
\text { + Sucrose }\end{array}$ & $265.10 \pm 22.93$ & $242.44 \pm 20.41$ & $127.34 \pm 3.98$ & $113.33 \pm 3.54$ & $194.18 \pm 12.15$ & $214.72 \pm 10.80$ \\
\hline \multirow{4}{*}{$\begin{array}{l}\text { L-MDA } \\
\text { (nmol/g. } \\
\text { tissue) }\end{array}$} & Control & $5.09 \pm 2.43$ & $7.48 \pm 2.30$ & $566.53 \pm 19.80$ & $583.75 \pm 18.81$ & $23.91 \pm 2.99$ & $32.28 \pm 2.84$ \\
\hline & $\begin{array}{l}\text { Sucrose } \\
\text { Stressed }\end{array}$ & $30.29 \pm 2.45$ & $35.49 \pm 2.27$ & $794.34 \pm 6.76$ & $739.16 \pm 6.28$ & $90.18 \pm 2.39$ & $98.88 \pm 2.22$ \\
\hline & $\begin{array}{c}\text { Kombucha } \\
\text { only }\end{array}$ & $5.72 \pm 1.04$ & $7.67 \pm 0.95$ & $\begin{array}{c}646.61 \pm \\
14.22\end{array}$ & $634.50 \pm 12.74$ & $28.44 \pm 1.97$ & $35.17 \pm 1.79$ \\
\hline & $\begin{array}{l}\text { Kombucha } \\
\text { + Sucrose }\end{array}$ & $12.90 \pm 3.28$ & $16.65 \pm 25.59$ & $736.29 \pm 8.29$ & $655.29 \pm 7.37$ & $50.27 \pm 2.04$ & $42.80 \pm 1.81$ \\
\hline \multirow{4}{*}{$\begin{array}{c}\mathrm{H}_{2} \mathrm{O}_{2} \\
\text { (mM/g. } \\
\text { tissue) }\end{array}$} & Control & $13.95 \pm 0.77$ & $16.54 \pm 0.73$ & $0.75 \pm 0.05$ & $0.82 \pm 0.04$ & $0.71 \pm 0.09$ & $0.79 \pm 0.08$ \\
\hline & $\begin{array}{l}\text { Sucrose } \\
\text { Stressed }\end{array}$ & $39.04 \pm 1.01$ & $45.85 \pm 0.93$ & $3.17 \pm 0.05$ & $4.17 \pm 0.04$ & $4.51 \pm 0.38$ & $5.34 \pm 0.35$ \\
\hline & $\begin{array}{c}\text { Kombucha } \\
\text { only }\end{array}$ & $10.87 \pm 2.33$ & $14.11 \pm 2.12$ & $0.69 \pm 0.04$ & $0.73 \pm 0.03$ & $0.34 \pm 0.06$ & $0.38 \pm 0.05$ \\
\hline & $\begin{array}{l}\text { Kombucha } \\
+ \text { Sucrose }\end{array}$ & $20.70 \pm 0.62$ & $35.41 \pm 0.55$ & $1.85 \pm 0.05$ & $1.77 \pm 0.04$ & $1.89 \pm 0.04$ & $1.66 \pm 0.03$ \\
\hline
\end{tabular}


Moreover, hypertriglyceridemia after simple carbohydrate feeding results from the induction of denovo lipogenesis, the enhanced rate of hepatic VLDL, triglyceride synthesis and a decrease in peripheral triglyceride clearance ${ }^{26}$.

In addition ${ }^{18}$, reported that, glucose intolerance and insulin resistance is associated with dyslipidemia and characterized by high levels of TC, LDL-C, non esterified fatty acid and glycerol with a significant low level of HDL-C. In addition, in subjects consuming fructose, significant increased circulating levels of remnant lipoproteins, small dense LDL and oxidized LDL were reported ${ }^{25}$.

Fructose feeding can induce free radical formation by a number of mechanisms. It causes down regulation of the key enzymes of the hexose monophosphate pathway, namely glucose-6-phosphate dehydrogenase and 6-phosphogluconate dehydrogenase that generate a reduced environment in the form of NADPH and $\mathrm{NADH}$. Impaired regeneration of NADPH could result in an increased oxidative state of the cell ${ }^{27}$.

Our study is in accordance with ${ }^{19}$ who reported that fructose enriched diet, resulted in increased lipid peroxidation and impaired antioxidant status. Moreover ${ }^{24}$, reported that, increases in the levels of the Thiobarbituric Acidreactive Substances (TBARS) and hydroperoxides were observed in the liver of fructose fed rats.

$\mathrm{In}^{7}$ reported that the increased rate of $\mathrm{H}_{2} \mathrm{O}_{2}$ generation in high sucrose diet rat could result from decreased levels of reduced CoQ10, vitamin $\mathrm{E}$ and reduced glutathione and elevated activity of $\mathrm{Cu} / \mathrm{Zn}$-SOD in the mitochondrial intermembrane space. The excess $\mathrm{H}_{2} \mathrm{O}_{2}$ in the inter membrane space may cross the external mitochondrial membrane and affect the redox state of the entire liver by decreasing the concentration of reduced GSH. Additionally, the reduced activity of catalase observed in sucrose fed rats liver homogenate may contribute to increased levels of lipid peroxidation and protein carbonylation in whole liver cells ${ }^{8}$.

Kombucha prevents central body fat accumulation and decreases postprandial adiponectin expression induced by a carbohydrate rich diet in insulin resistant subjects $^{4}$. Our results nearly similar to ${ }^{11}$ that a decrease in serum triacylglycerol, VLDL concentration after administration of Kombucha tea (Table 1) due to low activity of hydroxyl methyl glutaryle Co A responsible for cholesterol synthesis. Also ${ }^{29}$, observed that, hypocholestermic effect of Kombucha tea (Table 2) refer to present gluconoaceto bacteria sp4 that attributed to modified Kombucha tea has powerful effect.

Kombucha tea exhibit hypoglycemic effect, reduced the insulin requirements and improved insulin resistance (Table 3) so, it increased the release of TG from the liver and decreased the flux of free fatty acids from peripheral adipose tissue back to the liver ${ }^{1}$. The administration of Kombucha resulted in reductions of total cholesterol concentration and transaminases activity in serum. Moreover, Kombucha been shown to be less susceptible to oxidation. This binding is directly related to an increase of the LDL resistance to oxidation ${ }^{22}$.

In addition, the anti-atherosclerotic effect (Table 2) of Kombucha demonstrated in rabbits on a high-lipid diet related to suppression of inflammation and decreasing the concentration of TG and LDL-C and improved the level of HDL-C that has been linked to a lower risk of coronary heart disease ${ }^{1}$.

The obtained data belonging to the effect of Kombucha on testosterone concentration (Table 4) nearly agree with $^{20}$ that, Kombucha significantly decreased serum testosterone as well as sperm count, sperm motility, the weight of prostate, testis, epididymis, seminal vesicle, weights of the testicle and seminal vesicle. Moreover, Kombucha is known as a phytoestrogen compound since it contains phenolic compounds ${ }^{15}$. Also ${ }^{16}$ reported that, the Kombucha contains phytoestrogen which may has an inhibitory effect on the enzyme 17- B-hydroxy steroid hydrogenase, therefore, the synthesis of testosterone in adrenal cortex is reduced.

The significant decrease of testosterone level after administration of Kombucha tea may attribute to hypocholesterolemic effect which may be decrease the testosterone testicular synthesis. The inhibition of denovo synthesis pathway of cholesterol biosynthesis negatively affects testosterone level in addition to cholesterol concentration in the tissues, body weight gain and ALT with no successful compensatory mechanism as related with testosterone level ${ }^{17}$.

Moreover, in males, it was demonstrated that testosterone biosynthesis requires a continuous cholesterol supply ${ }^{12}$ so the inhibition of cholesterol 
biosynthesis pathway may results in a decline in plasma testosterone concentration which may lead to a marked decrease in the fertility index and sperm cell count ${ }^{23}$.

Kombucha improved oxidative stress and repair any damage which generates free radicals and alters antioxidants scavenging enzyme (Table 5$)^{28}$. The results was in accordance with ${ }^{21}$ that, the administration of purified Kombucha is able to reduce the oxidative damage and suppresses oxidative stress as monitored by the elevation activity of the main anti-peroxidative enzyme, catalase and decreases lipid peroxidation products in liver.

In addition, the positive impact of treatment with Kombucha on the antioxidant enzymes GPx, GRx, CAT and SOD could be explained with two possible mechanisms. First, the antioxidant effect of Kombucha may prevent further glycosylation and peroxidation of proteins by interacting with free radicals and hence minimizing their noxious effects. Second, Kombucha may induce protein synthesis of these enzymes as reported by ${ }^{28}$.

\section{Conclusion}

Our results conclude that, the administration of high sucrose diet to male rabbits accompany by significance disturbance of lipid profile and antioxidant system as well as increase levels of glucose, urea, creatinine and Kombucha tea was able to ameliorate serum biochemical parameters.

\section{References:}

1. Atwa SA. Biochemical study of Kombucha in Quail. [MSc. thesis in Biochemistry]. Fac Vet Med; Benha University; 2010.

2. Anuradha CV, Anurag P. Metformin improves lipid metabolism and attenuates lipid peroxidation in high fructose-fed rats. Diabetes Obes Metab. 2002; 4:36-42. PMid: 11874440. https://doi.org/10.1046/j.14631326.2002.00178. $\mathrm{x}$

3. Besty P, Sanford H. Kombucha phenomenon the miracle health tea how to safely make and use Kombucha. $2^{\text {nd }}$ ed. Sierra. 2016.

4. Brows E. Changes in free radical scavenging ability of Kombucha tea during fermentation. Food Chemistry. 2008; 109(I):227-34.
5. Busserolles J, Zimowska W, Rock E, Rayssiguier Y, Mazur A. Rats fed a high sucrose diet have altered heart antioxidant enzyme activity and gene expression. Life Sci. 2002; 71:1303-12. https://doi.org/10.1016/S00243205(02)01846-5

6. Chen C, Liu BY. Changes in major components of tea fungus metabolites during prolonged fermentation. Journal of Applied Microbiology. 2000; 89(5):834-9. PMid: 11119158. https://doi.org/10.1046/ j.1365-2672.2000.01188.x

7. Mohammed EH, Ruiz-Ramírez A, Chavez-Salgado M, Pe-eda-Flores JA, Zapata E,. Masso F. High-sucrose diet increases ROS generation, FFA accumulation, UCP2 level and proton leak in liver mitocondria. Am J Physiol Endocrinol Metab. 2011; 301(6):E1198-207. PMid: 21917631. https://doi.org/10.1152/ajpendo.00631.2010

8. El-Tabbakh IM. Effect of olive leaves and oil on some biochemical constituents in rabbits fed on high sucrose ration. [PhD Thesis in Biochemistry]. Fac Vet Mede. Alexandria University. 2014.

9. Hartmann AM, Burleson LE, Holmes AK, Geist CR. Effects of chronic Kombucha ingestion on open-field behaviors, longevity, appetitive behaviors and organs in c57-bl/6 mice: A pilot study. Nutrition. 2000; 16(9): 755-61. https://doi.org/10.1016/S0899-9007(00)00380-4

10. Wan H, Nikolas D, O’Doherty Robert M. Hepatic steatosis and plasma dyslipidemia induced by a high-sucrose diet are corrected by an acute leptin infusion. J Appl Physiol. 2007; 102:2260-5. PMid: 17363621. https://doi. org/10.1152/japplphysiol.01449.2006

11. Ibrahiem AA, ELsayed EM, Hafez SA, El-Zeini HM, Salah FA. The hypocholestermic effect of milk yoghurt and soy-yoghurt containing bifido bacteria in rat fedon a cholesterol enriched diet. International Dairy Journal. 20051 15(1):37-44. https://doi.org/10.1016/j.idairyj.2004.06.001

12. Kalo MS. Effect of cholesterol biosynthesis inhibitor on some biochemical parameters in normal male rats. Iraqi Journal of Veterinary Sciences. 2009; 23(1):5-12. https://doi.org/10.33899/ijvs.2009.5684

13. Kamari Y, Harari A, Shahish A, Peleg E, Sharabi Y, Harats D, Grossman E. Effect of telmisartan, angiotensin II receptor antagonist, on metabolic profile in fructoseinduced hypertensive, hyperinsulinemic, hyperlipidemic rats. Hypertens Res. 2008; 3:135-40. PMid: 18360028. https://doi.org/10.1291/hypres.31.135

14. Kaneko JJ. Kaneko JJ, Harvey JW, Bruss ML. Clinical biochemistry of domestic animals. San Diego, CA: Academic Press p. 46 ISBN 012370491. 2008.

15. Lee CP, Shih PH, HSV CL, Yen GC. Hepatoprotection of tea seed oil (camellia oleifera Abel) against $\mathrm{CCH}$. Induced oxidative damage in rats. Food and Chemical 
Toxicology. 2007; 45:888-95. PMid: 17188414. https://doi. org/10.1016/j.fct.2006.11.007

16. Liu $\mathrm{CH}$, Hsu WH, Lee FL, Liao CC. Isolation and identification of microbes from a fermented tea beverage, Hapiao and their interaction during Haipao fermentation. Food Microbiology. 1996; 13(6):407-15. https://doi. org/10.1006/fmic.1996.0047

17. Lopez-Miranda J, Badimon L, Bonanome A, Lairon D, Kris-Etherton PM, Mata P, et al. Monounsaturated fat and cardiovascular risk. Nutr Rev. 2016; 64(2):2-12.

18. Maurya SK, Srivastava AK. High fructose diet-induced glucose intolerance and dyslipidemia in adult Syrian golden hamsters. Indian Journal of Science and Technology. 2008; 1(6):1-5.

19. Nandhini AT, Thirunavukkarasu V, Ravichandran MK, Anuradha CV. Effect of taurine on biomarkers of oxidative stress in tissues of fructose-fed insulin-resistant rats. Singapore Med J. 2005; 46(2):82-7. PMid: 15678290.

20. Ola AG. Effect of Kombucha on oxidative stress induced nephro toxicity in rats. Chin Med. 2009; 4:23. PMid: 19943946 PMCid: PMC2788564. https://doi. org/10.1186/1749-8546-4-23

21. Radomir V, Malbasa RV, Eva S. lancan and ljitjana A. Kolarov. Tea fungus fermentation a substrate with iron (II) ions. Acta Periodica Technologica. 2002; 33:143-9.

22. Ram M, Anju B, Pauline T, Dipti P, Kain AK, Mongiass, Sharmask, Singh B, Singh R, Ilavazhagan G, Kumar D, Selvamurthyw. Effect of Kombucha tea on chromate induced oxidative stress in albino rats. J Ethnopharmacol. 2000; 71(1-2):235-40. https://doi.org/10.1016/S03788741(00)00161-6
23. Shalaby MA, el-Zorba HY, Kamel GM. Effect of alpha tocopherol and simvastatin on male fertility in hypercholesterolemic rats. Pharmacol Res. 2004; 50(2):137-42. PMid: 15177301. https://doi.org/10.1016/j.phrs.2003.10.013

24. Srividhya S, Anuradha,C. Metformin improves liver antioxidant potential in rats fed a high-fructose diet. Asia Pacific J Clin Nutr. 2007; 11(4):319-22. PMid: 12495266. https://doi.org/10.1046/j.1440-6047.2002.00306.x

25. Stanhope KL, Griffen S, Krauss RM, et al. Consumption of fructose-, but not glucose-sweetened beverages produces an atherogenic lipid profile in overweight/obese men and women. J Clin Invest. 2007; 119:1322-34. PMid: 19381015 PMCid: PMC2673878. https://doi.org/10.1172/JCI37385

26. Suzuki T, Hara H. Ingestion of guar gum hydrolysate, a soluble and fermentable non digestible saccharide, improves glucose intolerance and prevents hypertriglyceridemia in rats fed fructose. J Nutr. 2004; 134(8):1942-7. PMid: 15284380. https://doi.org/10.1093/jn/134.8.1942

27. Taniguchi M, Cherian MG. Antigenic changes in hepatic glutathione and metallothionein in rats and the effect of a low sulfur containing diet. Br J Nutr. 2010; 63:97-103. https://doi.org/10.1079/BJN19900095

28. Yousef NS. Tea extracts as possible natural food preservative for organic food. Acta Hortic. 2003; 608:169-76. https://doi.org/10.17660/ActaHortic.2003.608.21

29. Zhi-Wei Y, Baping FZ, Boli YC, Liyang T. The hypocholestermic and antioxidants effects of Kombucha tea in high cholesterol fed mice. Journal of the Science of Food and Agriculture. 2009; 89:150-6. https://doi.org/10.1002/ jsfa. 3422 